\title{
Assessing the risk of vulnerable species exposure to deepwater trawl fisheries: the case of orange roughy Hoplostethus atlanticus to the west of Ireland and Britain
}

\author{
Leonie DrANSFELD ${ }^{1, a}$, Hans D. GERRITSEN ${ }^{1}$, Nils R. HAREIDE ${ }^{2}$ and Pascal LORANCE ${ }^{3}$ \\ 1 Marine Institute, Rinville, Oranmore, Co. Galway, Ireland \\ 2 Runde Environmental Centre, 6096 Runde, Norway \\ 3 IFREMER, rue de l'Île d'Yeu, B.P. 21105, 44311 Nantes Cedex 03, France
}

Received 11 April 2013; Accepted 4 November 2013

\begin{abstract}
With slow growth rates, late maturity and a high maximum age of 100 years or more, orange roughy can be classified as a vulnerable deepwater fish species that can only sustain low rates of exploitation. Historical patterns of exploitation associated with this species suggest that it is currently not possible to manage its fisheries in the Northeast Atlantic sustainably, and the total allowable catch for orange roughy has been gradually reduced to zero for European fisheries since 2010. Orange roughy to the west of Ireland and Britain occurs on distinct bathymetric features (seamounts, hills and canyons) as well as on flat ground along the continental slope. Productivity-susceptibility analysis (PSA) was performed to evaluate the biological vulnerability of orange roughy in relation to other deepwater species and the risk that recent and current fisheries pose to its populations in the study area. Time-dependant PSA, based on the spatial overlap between orange roughy distribution and recent and current deepwater fisheries demonstrated a strong reduction in risk over time when fisheries stopped directed targeting practices and continued with mixed deepwater trawl fisheries. Some spatial overlap between the species and current fisheries remains, and while the method can show relative risk reduction, it cannot provide information on whether the risk is low enough to allow the recovery of depleted populations.
\end{abstract}

Keywords: Ecological risk assessment / VMS / Continental slope / Beryciformes / Atlantic Ocean

\section{Introduction}

With slow growth rates, late maturity and a high maximum age of 100 years or more orange roughy Hoplostethus atlanticus (Collett, 1889) can be classified as a vulnerable deepwater fish species that can only sustain low rates of exploitation. In the Northeast Atlantic, the species has been subjected to directed fisheries, targeting spawning aggregations on seamounts and hills (Clark 2001; Andrews et al. 2009) and mixed trawl fisheries fishing for deepwater species, including roundnose grenadier (Coryphaenoides rupestris), black scabbardfish (Aphanopus carbo), blue ling (Molva dypterygia) and deepwater sharks along the continental slope. Landings statistics show that the continental slopes and seamounts, e.g. Hebrides Terrace, to the west of the British Isles produced the highest accumulated catch of this species in the North Atlantic (34000 tons) between 1988 and 2008. The directed fishery for orange roughy to the west of Ireland and Britain started in the early 1990s in ICES Division VIa (Fig. 1), where it was rapidly depleted and the fishery ceased (ICES 2011). The

\footnotetext{
a Corresponding author: leonie.dransfeld@marine.ie
}

deepwater mixed fishery continued, however, on other target species. Fisheries moved towards ICES Subarea VII in early 2000 and peaked in 2002 with landings over $5000 \mathrm{t}$ of orange roughy taken in Subarea VII for that year. Thereafter, catch rate data also suggested sequential depletion of local aggregations. A total allowable catch (TAC) was introduced for orange roughy in ICES Subareas VI and VII from 2003 onwards. Spatial management measures were also implemented around the Porcupine Bank. EU TAC was drastically reduced between 2006 and 2009 and has been set at zero since 2010 .

The catch limit for orange roughy in ICES Subareas VII and VI is zero: the species cannot be landed by the EU fleet. However, a mixed deepwater trawl fishery is still operating to the west of the British Isles and, as a zero TAC does not allow landing of bycatch, this could lead to discarding.

Productivity-susceptibility analysis (PSA) is a semiquantitative approach that can be used in data-poor situations to evaluate the risk that fisheries pose to fish populations (Hobday et al. 2007; Patrick et al. 2010). PSA examines the attributes of a population so as to evaluate its vulnerability to a particular fishery. Productivity is the average of attribute scores relating to life history characteristics and includes age and size 


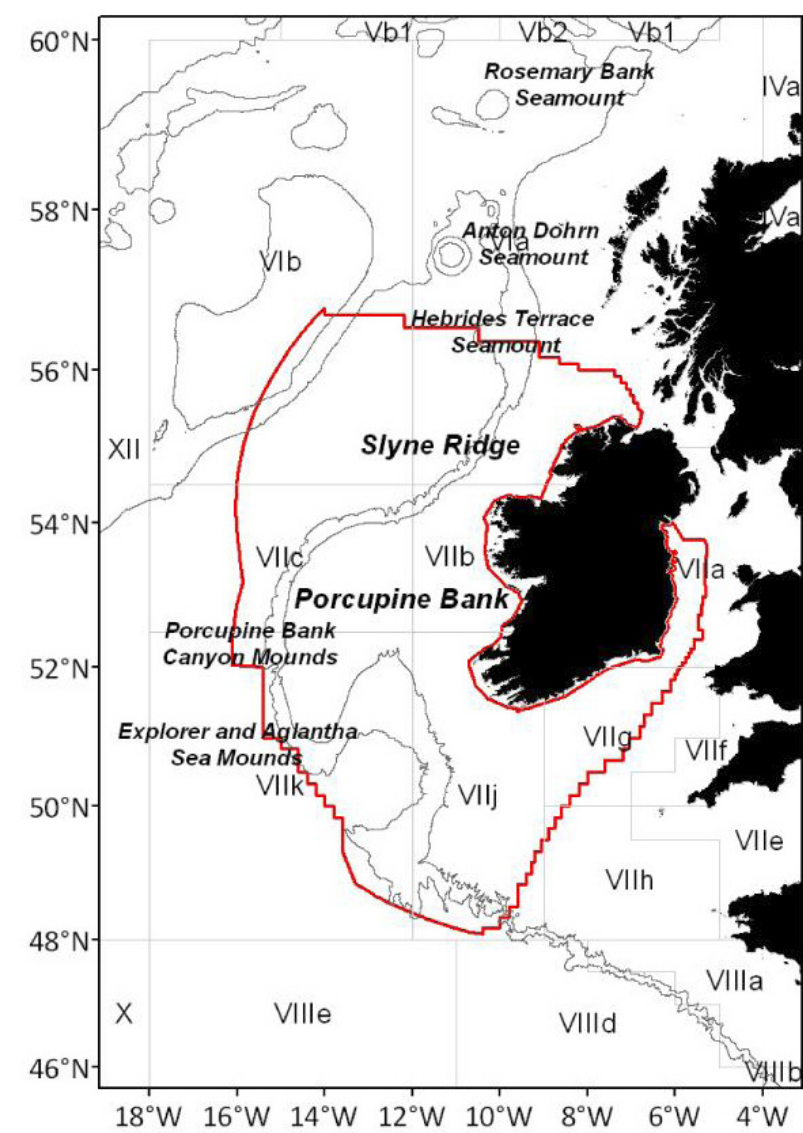

(a)

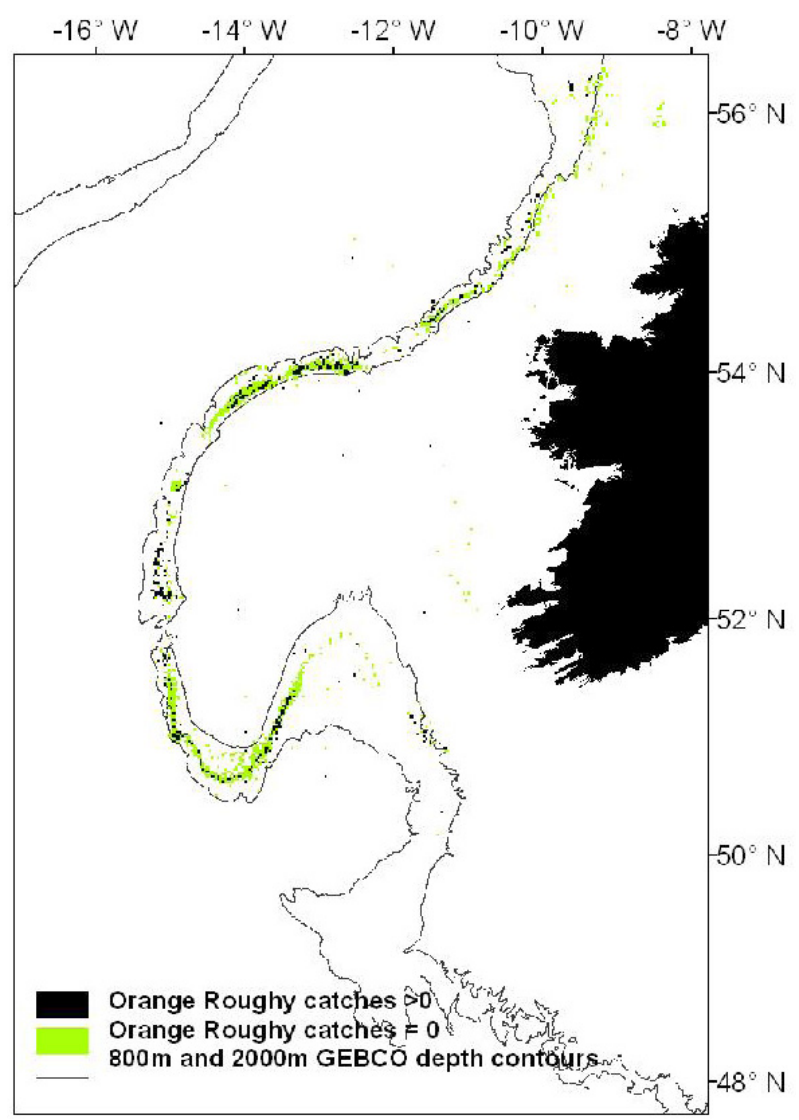

(b)

Fig. 1. (a) The west of the British Isles with the Irish EEZ (red dashed lines), depth contours (dark grey), ICES divisions (light grey) and geographical areas mentioned in the text (left panel) and (b) spatial positions of orange roughy catches in the Irish EEZ between 2001 and 2011 derived from scientific trawl surveys, fisheries observer programmes and VMS-logbook analysis as gridded sums at a resolution of 1.8 min longitude by $1.2 \mathrm{~min}$ latitude (right panel). Contour lines in light grey present the $800 \mathrm{~m}$ and $2000 \mathrm{~m}$ depth bands.

at maturity, maximum age and size, fecundity and reproductive strategy as well as trophic level. Susceptibility is the product of attributes relating to a particular fishery and includes the availability of a stock to the fishery, i.e. its distribution and behavioural characteristics. Susceptibility attributes consider the overlap of fishing effort with the population distribution and the encounterability, which is the likelihood that the population will encounter fishing gear that is deployed within its geographic distribution area. The third and fourth susceptibility attributes comprise selectivity, which considers the potential of the gear to capture or retain a species, and post-capture mortality. In this study, two PSAs were applied to evaluate to what extent local orange roughy aggregations to the west of Britain and Ireland are vulnerable to deepwater fisheries. The first PSA comprised a standard multispecies comparison with the objective to assess the relative vulnerability of orange roughy in relation to other species typically caught in the mixed deepwater trawl fishery to the west of Ireland and Britain. The second PSA is a new application that comprised a time-dependent evaluation of the susceptibility of orange roughy to deepwater fisheries in recent years using high resolution spatial data on species distribution and fisheries. The assumption was that the productivity of the population does not change over years, but the susceptibility to fisheries can be examined and evaluated. The objective was to determine to what extent the introduced management measures have reduced the relative susceptibility of a vulnerable species to particular fisheries.

\section{Materials and methods}

\subsection{VMS analysis}

In EU waters, all fishing vessels $>15 \mathrm{~m}$ are required to transmit their position and speed at least every $2 \mathrm{~h}$ via Vessel Monitoring Systems (VMS) by satellite (EC 2003). Spatial and temporal distributions of the French and Irish Deepwater fisheries in the part of ICES Subareas VI and VII that is within Ireland's exclusive economic zone (EEZ), were derived from VMS data between 2006 and 2011. France and Ireland were the two main nations operating deepwater fisheries within the Irish EEZ at this time (ICES 2012). Irish deepwater fisheries were identified by linking VMS data to logbook data (see Gerritsen and Lordan 2011) and selecting vesseldays where the retained catches contained at least $50 \%$ deepwater species. Species were classified as deepwater species 
if they were listed in annex 1 of the European deepwater access scheme (EC 2002). French deepwater fisheries were identified by only selecting vessels with deepwater fishing licenses defined by the same regulation. In addition, positions of both data sets were only selected if they fell between the 800-2000 m contour lines. Exploratory survey data prior to the development of deepwater fishing suggest that although orange roughy may occasionally be caught in small numbers shallower than $800 \mathrm{~m}$ to the West of the British Isles, only a minor proportion of the population may occur at such "shallow" depths (Bridger 1978; Ehrich 1983). Abundance increases over the depth range 800-1200 $\mathrm{m}$ and abundance reduction from fisheries can be expected to have further reduced occurrence in the non-preferred (including shallow) parts of the species habitat. Fishing positions were identified by applying a speed filter (instantaneous vessel speeds between 1.5 and 4.5 knots were assumed to correspond to fishing) and for each fishing position, the time interval since the previous VMS record was taken as the fishing effort (Gerritsen and Lordan 2011). Deepwater effort from France and Ireland was mapped on a grid with the spatial resolution of 1.8 min longitude by 1.2 min latitude (approx. 1.1 to 1.2 nautical miles) using the R-package mapplots in R 2.15.1. Fishing effort (in hours) and mean depth were estimated for each grid cell by country and year. The area fished was calculated by adding up the surface area (in nautical mile ${ }^{2}$ ) of all the cells with $>0$ effort and also that of the cells with $>3 \mathrm{~h}$ and $>5 \mathrm{~h}$ effort, whereby area is calculated in the $x, y$ domain and does not account for variations in depth. Note that this is an index - not an absolute estimate - of the area of the seafloor that is impacted by trawling, see Gerritsen et al. (2013) for details on estimating absolute estimates. The choice of the grid size was a compromise between spatial resolution and the number of VMS records in each grid cell. Here, grid cells were chosen to be roughly equivalent to the area covered by the gear in a 2 -h period (assuming a fishing speed of 3.5 knots and a door spread of $100 \mathrm{~m}$ ).

\subsection{Distribution of orange roughy}

Spatial catch information on orange roughy within the Irish EEZ was compiled from scientific observer programmes, scientific surveys and high resolution catch data based on VMS and Irish logbook analysis. Data from deepwater surveys included the orange roughy acoustic survey programme carried out on Porcupine Bank in 2005, the Irish deepwater trawl survey, which sampled the European shelf slope between 53.5 and $57^{\circ} \mathrm{N}$ and the northern Porcupine Bank between 2006 and 2009, and data from the Scottish Deepwater survey, which sampled the Scottish slope between $55^{\circ} \mathrm{N}$ and $60^{\circ} \mathrm{N}$ for the years 2000 to 2011. See O'Donnell et al. (2007), Neat and Burns (2010) and Johnston et al. (2010) for survey details. For the high resolution commercial catch data, daily retained catches of orange roughy from the Irish vessel logbooks were allocated to the fishing positions for each vessel-day (see above for details on VMS analysis); e.g., if a vessel on a given date had 10 fishing positions and a daily retained catch of $200 \mathrm{~kg}$ of orange roughy, the assumed catch at each of the fishing positions would be $20 \mathrm{~kg}$. Overall, 2340 catch records with positional and depth information were compiled, which included 502 records with orange roughy catches above zero. The catch position data from all years were gridded at a spatial resolution of $1.8 \mathrm{~min}$ longitude and $1.2 \mathrm{~min}$ latitude, corresponding to the same grid dimensions as the VMS data. This provided a single distribution for the species, not a time series. Positional information translated into 1230 grid cells within the Irish EEZ, 355 of which contained positive orange roughy catches.

\subsection{Productivity susceptibility analyses}

Two productivity susceptibility analyses (PSA) were carried out following methods described by Hobday et al. (2007, 2011) using a modified version of the Marine Stewardship Council (MSC) assessment worksheets. The first PSA was a multi-species comparison of species that are typically caught in the mixed deepwater trawl fishery west of Ireland and Scotland (ICES subareas VI and VII) and included five teleosts and three elasmobranchs. Productivity scores were calculated for seven attributes, based on biological data derived from published literature using Northeast Atlantic estimates where available (Table 1). Scoring categories were adjusted from Hobday et al. (2007) to account for the overall longevity of the species examined and their body sizes (Table 2). Susceptibility scores were based on the four attributes availability, encounterability (vertical overlap between fish distribution and fishery), selectivity and death after capture, as described by Hobday (2007), and two additional attributes that included seasonal migration and schooling, aggregation and other behavioural responses (Patrick et al. 2010). Data for the susceptibility attributes were selected from the published literature (Gordon and Duncan 1985; Merrett et al. 1991; Gordon and Bergstad 1992; Priede et al. 2011; Marine-Institute 2012); scoring categories are shown in Table 2.

The second PSA focused only on one species, orange roughy, but analysed the change of susceptibility over time. Availability is the spatial overlap of fishing effort distribution with the distribution of a population. In this study, it was calculated by summing the grid cells of the orange roughy distributional area that intersected with the grid cells of VMS deepwater effort for every year and expressing them as a percentage of the total orange roughy distribution area using the following formula:

$$
\frac{\sum_{i=1}^{n}\left[C_{i}\right] \cap E_{i}}{\sum_{i=1}^{n} C_{i}} \times 100 .
$$

Whereby $C$ are the grid cells that contain orange roughy catches and $E$ are the grid cells that contain deepwater effort.

Instead of scoring this attribute according to categories as proposed by Hobday et al. (2007), availability was converted into a continuous score between 1 and 3 as a direct linear function of \% overlap to highlight any progressive changes with time. Note that using the orange roughy distribution for all years described above implies that this estimated distribution captures the potential distribution of orange roughy using all available information, and does not account for any possible spatial contraction due to declining abundance. In addition, the area distribution of orange roughy was not weighted by abundance, catch weight or habitat preference. Seasonal migration 
Table 1. Life history characteristics, references, productivity, susceptibility and combined PSA scores for eight species caught in the mixed deepwater trawl fishery west of Ireland and Britain. Trophic levels are derived from Fishbase, accessed in June, 2013. Abbreviations: BS broadcast spawner, LB: Life bearer. *Squaliformes are ovoviviparous.

\begin{tabular}{|c|c|c|c|c|c|c|c|c|}
\hline Attribute & $\begin{array}{l}\text { Roundnose } \\
\text { grenadier } \\
\text { Corypha- } \\
\text { enoides } \\
\text { rupestris } \\
\text { (RNG) }\end{array}$ & $\begin{array}{c}\text { Black } \\
\text { scabbardfish } \\
\text { Aphanopus } \\
\text { carbo } \\
\text { (BSF) }\end{array}$ & $\begin{array}{c}\text { Greater } \\
\text { forkbeard } \\
\text { Phycis } \\
\text { blennoides }\end{array}$ & $\begin{array}{l}\text { North } \\
\text { Atlantic } \\
\text { codling } \\
\text { Lepidion } \\
\text { eques } \\
\text { (LPE) }\end{array}$ & $\begin{array}{c}\text { Orange } \\
\text { Roughy } \\
\text { Hoplostethus } \\
\text { atlanticus } \\
\text { (ORY) }\end{array}$ & $\begin{array}{l}\text { Velvet belly } \\
\text { Etmopterus } \\
\text { spinax }\end{array}$ & $\begin{array}{c}\text { Portuguese } \\
\text { dogfish } \\
\text { Centro- } \\
\text { scymnus } \\
\text { coelolepis } \\
\text { CYO }\end{array}$ & $\begin{array}{c}\text { Leafscale } \\
\text { gulper shark } \\
\text { Centrophorus } \\
\text { squamosus }\end{array}$ \\
\hline $\begin{array}{l}\text { Age at } \\
\text { maturity } \\
\text { (female, year) }\end{array}$ & $\begin{array}{c}14 \\
\text { (Allain 2001) }\end{array}$ & $\begin{array}{c}3-4 \\
\text { (Pajuelo et al. } \\
2008)\end{array}$ & $\begin{array}{c}\text { 3-4 (Med) } \\
\text { (Muus and } \\
\text { Nielsen 1999) }\end{array}$ & $\begin{array}{c}8-9 \\
\text { (Magnusson } \\
\text { 2001) }\end{array}$ & $\begin{array}{c}30 \\
\text { (Shephard } \\
\text { and Rogan } \\
\text { 2004) }\end{array}$ & $\begin{array}{c}9 \\
\text { (Coelho and } \\
\text { Erzini 2008) }\end{array}$ & $\begin{array}{c}22 \\
\text { (Moura and } \\
\text { Figueiredo } \\
\text { 2013) }\end{array}$ & $\begin{array}{c}25 \\
\text { (Clarke et al. } \\
2003)\end{array}$ \\
\hline
\end{tabular}

\begin{tabular}{|c|c|c|c|c|c|c|c|c|}
\hline PSA score & 2 & 1 & 1 & 2 & 3 & 2 & 3 & 3 \\
\hline $\begin{array}{l}\text { Maximum age } \\
\text { (year) }\end{array}$ & $\begin{array}{l}60 \text { (Kelly } \\
\text { et al. 1997) }\end{array}$ & $\begin{array}{l}32 \text { (Kelly } \\
\text { et al. 1998) }\end{array}$ & $\begin{array}{l}14 \text { (Casas and } \\
\text { Pineiro 2000) }\end{array}$ & $\begin{array}{c}13 \\
\text { (Magnusson } \\
2001)\end{array}$ & $\begin{array}{c}>130 \text { in NE } \\
\text { Atl. } \\
\text { (Shephard } \\
\text { and Rogan } \\
\text { 2004) }\end{array}$ & $\begin{array}{c}11 \\
\text { (Coelho and } \\
\text { Erzini 2008) }\end{array}$ & $\begin{array}{c}50 \\
\text { (Moura and } \\
\text { Figueiredo } \\
\text { 2013) }\end{array}$ & $\begin{array}{l}70 \text { (Clarke } \\
\text { et al. 2002) }\end{array}$ \\
\hline
\end{tabular}

\begin{tabular}{lcccccccc}
\hline PSA score & 2 & 1 & 1 & 1 & 3 & 1 & 2 & 2 \\
\hline Fecundity & $4-70\left(\times 10^{3}\right)$ & $73-373$ & $2.6 \times 10^{6}$ & $3.5 \times 10^{3}-$ & $9.7 \times 10^{4}$ & $2-18$ young & $10-21$ young & $6-11$ young \\
& oocytes per & oocytes g & oocytes $\mathrm{mm}^{-2}$ & $11 \times 10^{6}$ eggs & oocytes per & per litter* & per litter* & per litter* \\
& batch & female & female & per female & female & (Coelho and & (Clarke et al. & (Clarke et al. \\
& (Allain 2001) & (Neves et al. & (Rotllant & (Gordon and & (Minto and & Erzini 2008) & 2001) & 2001)
\end{tabular}

\begin{tabular}{|c|c|c|c|c|c|c|c|c|}
\hline & & 2009) & et al. 2002) & Duncan 1985) & Nolan 2006) & & & \\
\hline PSA score & 1 & 1 & 1 & 1 & 1 & 3 & 3 & 3 \\
\hline $\begin{array}{l}\text { Maximum size } \\
(\mathrm{TL}, \mathrm{cm})\end{array}$ & $\begin{array}{c}148^{(1)} \\
\text { (Allain 2001) }\end{array}$ & $\begin{array}{c}151 \\
\text { (Figueiredo } \\
\text { et al. 2003) }\end{array}$ & $\begin{array}{l}81 \text { (Casas and } \\
\text { Pineiro 2000) }\end{array}$ & $\begin{array}{c}49 \\
\text { (Magnusson } \\
\text { 2001) }\end{array}$ & $\begin{array}{c}76^{(2)} \\
\text { (Shephard } \\
\text { and Rogan } \\
\text { 2006) }\end{array}$ & $\begin{array}{c}60 \\
\text { (Coelho and } \\
\text { Erzini 2008) }\end{array}$ & $\begin{array}{c}121 \\
\text { (Clarke et al. } \\
2001)\end{array}$ & $\begin{array}{c}145 \\
\text { (Clarke et al. } \\
\text { 2003) }\end{array}$ \\
\hline
\end{tabular}

\begin{tabular}{|c|c|c|c|c|c|c|c|c|}
\hline PSA score & 3 & 3 & 2 & 1 & 2 & 2 & 3 & 3 \\
\hline $\begin{array}{l}\text { Size at maturity } \\
(\text { female }, \mathrm{cm})\end{array}$ & $\begin{array}{c}56 \\
\text { (1) } \\
\text { (Allain 2001) }\end{array}$ & $\begin{array}{c}103 \\
\text { (Figueiredo } \\
\text { et al. 2003) }\end{array}$ & $\begin{array}{c}33 \\
\text { (Cohen et al. } \\
1990)\end{array}$ & $\begin{array}{c}30.2 \\
\text { (Magnusson } \\
\text { 2001) }\end{array}$ & $\begin{array}{c}\text { 44-47 }{ }^{(2)} \\
\text { (Shephard } \\
\text { and Rogan } \\
\text { 2006) }\end{array}$ & $\begin{array}{c}38 \\
\text { (Coelho and } \\
\text { Erzini 2005) }\end{array}$ & $\begin{array}{c}102 \text { (Girard } \\
\text { and Du Buit } \\
\text { 1999) }\end{array}$ & $\begin{array}{c}124 \\
\text { (Girard and } \\
\text { Du Buit } \\
\text { 1999) }\end{array}$ \\
\hline
\end{tabular}

\begin{tabular}{|c|c|c|c|c|c|c|c|c|}
\hline & & & & & & & & \\
\hline PSA score & 2 & 3 & 1 & 1 & 1 & 1 & 3 & 3 \\
\hline $\begin{array}{l}\text { Reproductive } \\
\text { strategy }\end{array}$ & $\begin{array}{l}\text { BS (Allain } \\
\text { 2001) }\end{array}$ & $\begin{array}{l}\text { BS (Neves } \\
\text { et al. 2009) }\end{array}$ & $\begin{array}{l}\text { BS (Rotllant } \\
\text { et al. 2002) }\end{array}$ & $\begin{array}{c}\text { BS (Gordon } \\
\text { and Duncan } \\
1985) \\
\end{array}$ & $\begin{array}{c}\text { BS } \\
\text { (Pankhurst } \\
\text { et al. 1987) } \\
\end{array}$ & LB & LB & LB \\
\hline PSA score & 1 & 1 & 1 & 1 & 1 & 3 & 3 & 3 \\
\hline Trophic level & 3.5 & 4.5 & 3.7 & 3.2 & 4.3 & 3.8 & 4.4 & 4.2 \\
\hline PSA score & 3 & 3 & 3 & 2 & 3 & 3 & 3 & 3 \\
\hline $\begin{array}{l}\text { Total } \\
\text { Productivity } \\
\text { (average) }\end{array}$ & 2 & 1.9 & 1.4 & 1.3 & 2 & 2.1 & 2.9 & 2.9 \\
\hline Susceptibility & & & & & & & & \\
\hline Availability & 1 & 1 & 1 & 1 & 1 & 1 & 1 & 1 \\
\hline Encounterability & 2 & 3 & 2 & 2 & 3 & 2 & 2 & 3 \\
\hline Selectivity & 3 & 3 & 3 & 3 & 3 & 3 & 3 & 3 \\
\hline Mortality & 3 & 3 & 3 & 3 & 3 & 3 & 3 & 3 \\
\hline Migration & 2 & 1 & 2 & 2 & 1 & 2 & 2 & 2 \\
\hline Behaviour & 2 & 2 & 2 & 2 & 3 & 2 & 2 & 2 \\
\hline $\begin{array}{l}\text { Total } \\
\text { susceptibility } \\
\text { (multiplicative) }\end{array}$ & 1.6 & 1.4 & 1.6 & 1.6 & 1.7 & 1.6 & 1.6 & 2.3 \\
\hline $\begin{array}{l}\text { Total } \\
\text { PSA score }\end{array}$ & 2.6 & 2.4 & 2.1 & 2.1 & 2.6 & 2.7 & 3.3 & 3.7 \\
\hline
\end{tabular}

${ }^{1}$ For roundnose grenadier, a length conversion from Preanal length $(\mathrm{cm})=0.196 \mathrm{TL}+2.3$ was used (Lorance et al. 2001). ${ }^{2}$ For orange roughy, a length conversion: $\mathrm{SL}=0.813 \mathrm{TL}-1.94$ was used (Kulka et al. 2003). 
Table 2. Description of productivity and susceptibility attributes and associated scoring categories (readjusted from Hobday et al. 2007; Patrick et al. 2010).

\begin{tabular}{|c|c|c|c|}
\hline Attribute & $\begin{array}{c}\text { Low productivity } \\
\text { High risk } \\
\text { Score }=3 \\
\end{array}$ & $\begin{array}{c}\text { Medium productivity } \\
\text { High risk } \\
\text { Score }=2 \\
\end{array}$ & $\begin{array}{c}\text { High productivity } \\
\text { Low risk } \\
\text { Score }=1 \\
\end{array}$ \\
\hline Age at maturity (years) & $>20$ & $8-20$ & $<8$ \\
\hline Maximum age (years) & $>100$ & $50-100$ & $<50$ \\
\hline Fecundity (eggs per year) & 100 & $100-20000$ & $>20000$ \\
\hline Maximum size $(\mathrm{cm})$ & $>00$ & $50-100$ & $<50$ \\
\hline Size at maturity $(\mathrm{cm})$ & $>100$ & $50-100$ & $<50$ \\
\hline Reproductive strategy & Live bearer & Demersal egg layer & Broadcast spawner \\
\hline Trophic level & $>3.25$ & $2.75-3.25$ & $<2.75$ \\
\hline Susceptibility & $\begin{array}{c}\text { High susceptibility } \\
\text { High risk } \\
\text { Score }=3\end{array}$ & $\begin{array}{c}\text { Medium susceptibility } \\
\text { Medium risk } \\
\text { Score }=2\end{array}$ & $\begin{array}{c}\text { Low susceptibility } \\
\text { Low risk } \\
\text { Score }=1\end{array}$ \\
\hline $\begin{array}{l}\text { Availability } \\
\text { (overlap of species } \\
\text { range with fishery) }\end{array}$ & $>30 \%$ overlap & 10-30\% overlap & $<10 \%$ overlap \\
\hline $\begin{array}{l}\text { Encounterability } \\
\text { (Habitat and depth) }\end{array}$ & $\begin{array}{l}\text { High overlap with } \\
\text { fishing gear }\end{array}$ & $\begin{array}{l}\text { Medium overlap } \\
\text { with fishing gear }\end{array}$ & $\begin{array}{c}\text { Low overlap with } \\
\text { fishing gear }\end{array}$ \\
\hline Selectivity & $\begin{array}{l}>2 \text { times mesh size } \\
\text { to } 4 \mathrm{~m} \text { in length }\end{array}$ & $\begin{array}{l}1-2 \text { times mesh size } \\
\text { or } 4-5 \mathrm{~m} \text { in length }\end{array}$ & $\begin{array}{l}<\text { mesh size or } \\
>5 \mathrm{~m} \text { in length }\end{array}$ \\
\hline Post-capture mortality & $\begin{array}{c}\text { Retained species } \\
\text { or majority dead } \\
\text { when released } \\
\end{array}$ & Released alive & $\begin{array}{c}\text { Evidence of post } \\
\text { capture release } \\
\text { and survival } \\
\end{array}$ \\
\hline Seasonal migration & $\begin{array}{c}\text { Seasonal migration } \\
\text { increases overlap } \\
\text { with fishery }\end{array}$ & $\begin{array}{c}\text { Seasonal migration does } \\
\text { not substantially affect } \\
\text { overlap with fishery }\end{array}$ & $\begin{array}{c}\text { Seasonal migration } \\
\text { decreases overlap } \\
\text { with fishery }\end{array}$ \\
\hline $\begin{array}{l}\text { Schooling, aggregation } \\
\text { or other } \\
\text { behavioural responses }\end{array}$ & $\begin{array}{c}\text { Behaviour } \\
\text { increases } \\
\text { catchability }\end{array}$ & $\begin{array}{c}\text { Behaviour does } \\
\text { not substantially } \\
\text { affect catchability }\end{array}$ & $\begin{array}{c}\text { Behaviour } \\
\text { decreases } \\
\text { catchability }\end{array}$ \\
\hline
\end{tabular}

considers the susceptibility to fisheries due to migration and was considered here in the context of fishing practices that targeted seasonal migrations on seamounts and other bathymetric features. A high susceptibility was given for the years when directed seamount fisheries on orange roughy spawning aggregations were taking place; this score was reduced when the targeted fisheries ceased and only mixed trawl fisheries on deepwater slopes were being carried out (Table 3 ).

Overall PSA vulnerability scores for both PSA analyses were calculated as follows: (1) the individual productivity attributes were scored and averaged to obtain an overall productivity score; (2) the individual susceptibility attributes were scored and the scaled-product was used for the overall susceptibility score; (3) the risk scores were calculated as the Euclidian distances from the origin.

\section{Results}

\subsection{Distribution of orange roughy}

Positive catches of orange roughy were recorded between the south of the Porcupine Bank $\left(50^{\circ} \mathrm{N}\right)$ and the west of Scotland $\left(60^{\circ} \mathrm{N}\right)$ (Fig. 1). While catches were in general low
Table 3. Susceptibility and combined PSA scores for orange roughy time dependant PSA, measuring the change in spatial overlap and the change in fishing practices between 2006 and 2011.

\begin{tabular}{lccccc}
\hline & \multicolumn{5}{c}{ Susceptibility of orange roughy over time } \\
\cline { 2 - 6 } & 2006 & 2007 & 2008 & 2009 & 2010 \\
\hline Fishing effort & 14.4 & 9 & 6.3 & 5.5 & 4.8 \\
(hour $\times 1000)$ & 2.5 & 2.2 & 1.7 & 1.4 & 1.6 \\
Availability & 3 & 2 & 2 & 2 & 2 \\
Encounterability & 3 & 3 & 3 & 3 & 3 \\
Selectivity & 3 & 3 & 3 & 3 & 3 \\
Post-capture mortality & 3 & 2 & 2 & 1 & 1 \\
Migration & 3 & 3 & 3 & 3 & 3 \\
Behaviour & 2.6 & 2.0 & 1.7 & 1.3 & 1.4 \\
Total susceptibility & & & & \\
(multiplicative) & 3.3 & 2.8 & 2.7 & 2.4 & 2.4 \\
PSA Total Scores & & & & & \\
\hline
\end{tabular}

and dispersed, high values were noted in concentrated patches at around $54.5^{\circ} \mathrm{N}$ at the Slyne ridge, the northern and the western Porcupine Bank close to the Porcupine Bank Canyon mounds and to the southwest of the Porcupine Bank at the "Explorer" and "Aglantha" sea mounds. The depth distribution 
ranged from $831 \mathrm{~m}$ to $1800 \mathrm{~m}$, but was mainly concentrated around $1100 \mathrm{~m}$.

\subsection{Distribution of deepwater effort}

French and Irish deepwater effort (in the Irish EEZ) recorded with VMS was distributed along the continental slope with more intense effort southwest of Ireland and on the southern Porcupine Bank, as well as the northern side of the Porcupine Bank and west of Scotland (Fig. 2). Over the observed time period (2006 to 2011), there was a strong reduction in deepwater fishing effort by both countries. While Irish effort decreased $94 \%$ from almost $6000 \mathrm{~h}$ in 2006 to $344 \mathrm{~h}$ in 2011 , French effort decreased by $42 \%$ from 8600 to $5000 \mathrm{~h}$ in the same time frame (Fig. 3). Spatially, this reduction in effort was stronger to the south of $54^{\circ} \mathrm{N}$, particularly on Porcupine Bank. While in 2006, the northern, western and southern slopes of the bank were still intensely fished, only limited fishing continued on the northern slope in 2008 and one year later almost no deepwater fishing could be observed on the slopes of Porcupine Bank (Fig. 2). In 2009, some remaining deepwater fisheries could be observed to the southwest of Ireland, but by 2010/2011 this had decreased. In 2010 and 2011, some effort had returned to a small section on the northern slope of Porcupine Bank, but effort was most concentrated to the northwest of Ireland. Over the observed time period, the area fished by deepwater trawling decreased from 3800 to less than 1700 nautical mile ${ }^{2}$ (Fig. 4). The area exposed to more than 2.5 and $5 \mathrm{~h}$ fishing decreased by around 60\% between 2006 and 2011 .

\section{PSA analysis}

\subsection{Multispecies comparison}

Table 1 shows the biological characteristics of orange roughy and 7 other deepwater species typically caught in the mixed deepwater fishery in zones VI and VII and the associated productivity scores adjusted from Hobday et al. (2007), see Table 2 for scoring categories.

For orange roughy, average age at maturity and average maximum age indicated low productivity and resulted in high risk scores, as did the high trophic level. Due to its short body size, orange roughy scored as medium for maximum body size and low on size at maturity suggesting high productivity. Its fecundity (>20000 eggs per year) and reproductive strategy (broadcast spawner) also resulted in low scores, suggesting high productivity. Overall, orange roughy scored 2 in productivity, which is the midpoint and indicates a medium biological risk to fishing. Most of the teleost species scored lower on the productivity side, with North Atlantic codling (Lepidion eques) and greater forkbeard (Phycis blennoides) showing highest productivity (i.e., lowest vulnerability scores) and orange roughy and roundnose grenadier scoring highest (both with a score of 2) for vulnerability. The three elamobranchs all displayed lower productivity than the teleost species, but there were differences between the shorter lived and smaller species Etmopterus spinax and the two larger shark species Centroscymnus coelolepis and Centrophorus squamosus. All
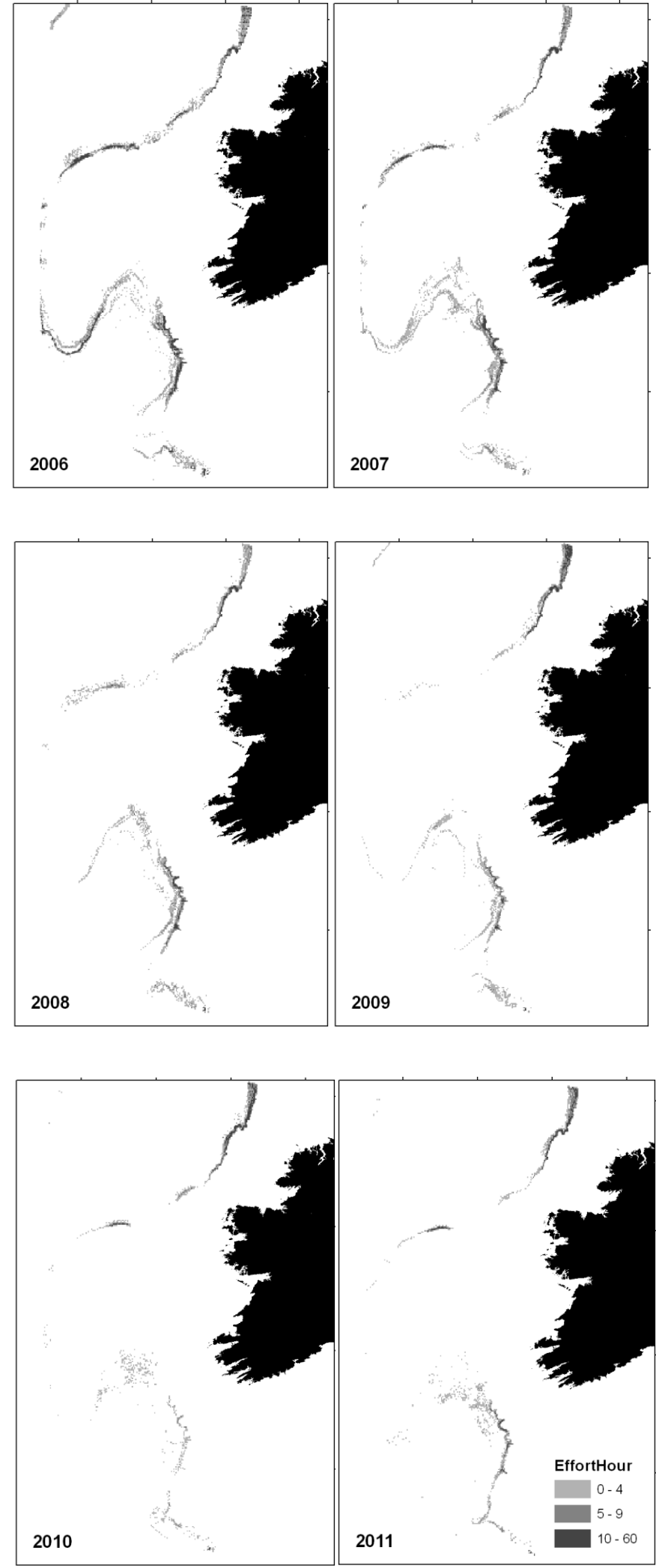

Fig. 2. Spatial positions of French and Irish deepwater fishing effort by VMS as the annual sum of hours within each grid cell between $800 \mathrm{~m}$ and $2000 \mathrm{~m}$ for the years 2006 to 2011. Contour lines in light grey present the $800 \mathrm{~m}$ and $2000 \mathrm{~m}$ depth bands. For definition of "deepwater effort" see materials and methods. 


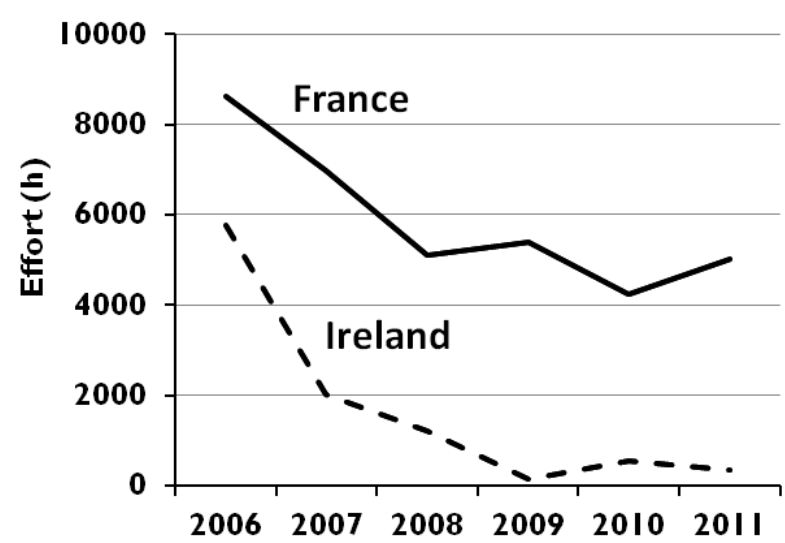

Fig. 3. Hours of Irish and French deepwater effort over time in the Irish EEZ, based on VMS data analysis.

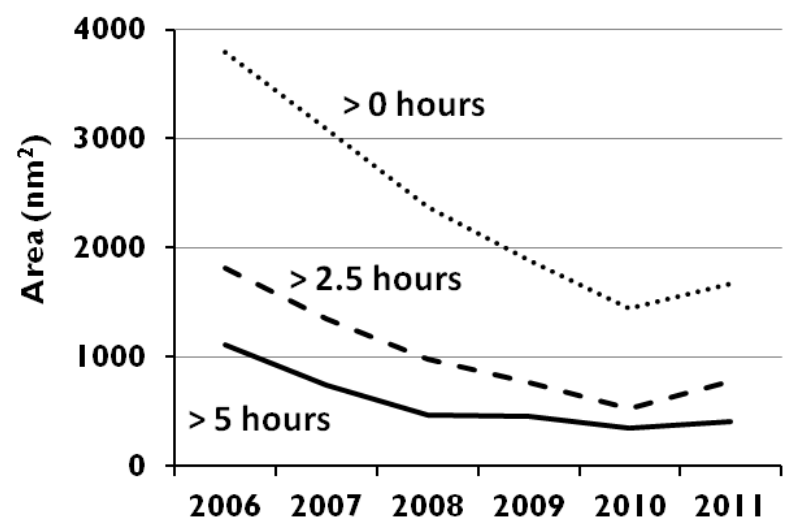

Fig. 4. Spatial footprint as the area impacted by adding up the surface area (in nautical mile ${ }^{2}$ ) of all the cells with $>0 \mathrm{~h}$ effort, $>2.5 \mathrm{~h}$ effort and $>5 \mathrm{~h}$ effort.

species received the same score for availability. Encounterability was measured as the depth overlap between the species distribution and the depth of the fishery. Encounterability scores were lower for Coryphaenoides rupestris, Centroscymnus coelolepis, Phycis blennoides, Lepidion eques and Etmopterus spinax, because a proportion of the first two species is distributed at deeper depths and a proportion of the latter three at shallower depths than the mixed deepwater trawl fishery. Migration patterns decrease susceptibility of black scabbardfish and orange roughy in relation to the deepwater mixed trawl fishery as these species migrate away from the fishing grounds, while the aggregating behaviour of orange roughy increases susceptibility. Note that the migration pattern of orange roughy only decreased its susceptibility after the direct fisheries on spawning migrations stopped (see below). Selectivity of gear type received a high susceptibility score for all species, as the individual sizes are at least twice the mesh size. Reaction to disturbance and differences in swimming capabilities may make escapement uncorrelated to girth in deepwater fish; for example, the black scabbardfish fish, which was seen swimming or drifting in a vertical position by ROV (Lorance and Trenkel 2006), may not be very capable of escaping through mesh. Sharks seem to be good swimmers that are mostly active, while orange roughy is often motionless

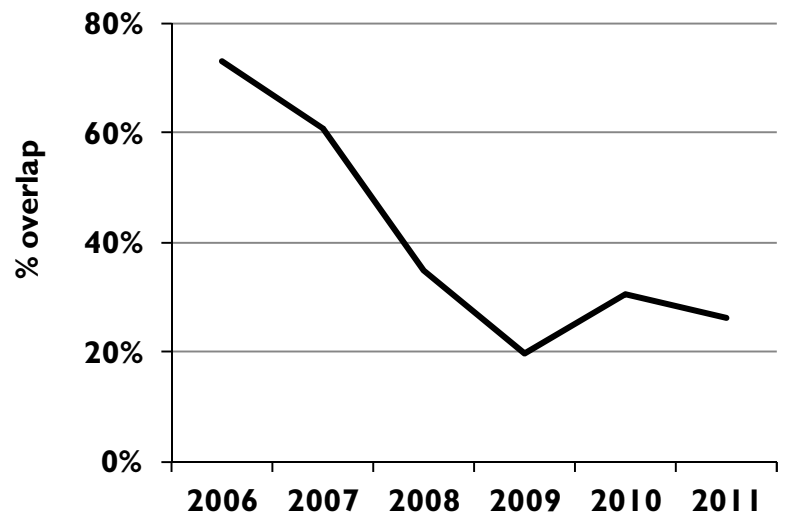

Fig. 5. Change in spatial overlap of orange roughy and deepwater fisheries (proportion of the orange roughy distribution area that intersected with the VMS deepwater effort area at a resolution of of 1.8 min longitude by 1.2 min latitude.

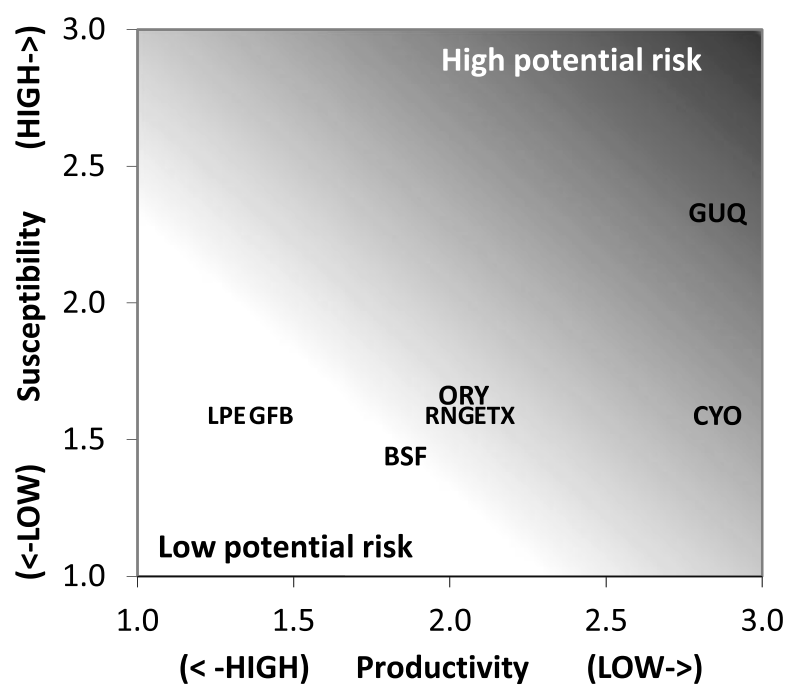

Fig. 6. Multispecies PSA plot: the $x$-axis gives average scores of the attributes that influence the productivity of eight deepwater species; the $y$-axis gives the scaled scores of attributes that influence the susceptibility of the species to the impacts from deepwater fishing in the study area to mixed deepwater trawl fisheries. Productivity and susceptibility scores are used to calculated the euclidian distance and indicate the relative risk of the fishery to the species. ORY: Orange roughy, RNG: Roundnose grenadier, BSF: Black scabbardfish, LPE: North Atlantic codling, GFB: Greater forkbeard, ETX Velvet belly, CYO: Portuguese dogfish, GUO: Leafscale gulper shark.

or passively drifting. The behaviour of all these species in trawls is unknown. It was therefore not possible to allocate different selectivity scores, and only size was considered. Postcapture mortality also resulted in high susceptibility scores for all species as they were either retained or were dead when released.

Overall, the species vulnerability to fishing is highest for two larger shark species, followed by orange roughy, Etmopterus spinax and roundnose grenadier (Fig. 6). The species Phycis blennoides and Lepidion eques have low scores due to their higher productivity, while black scabbardfish has lower values due to lower susceptibility. 


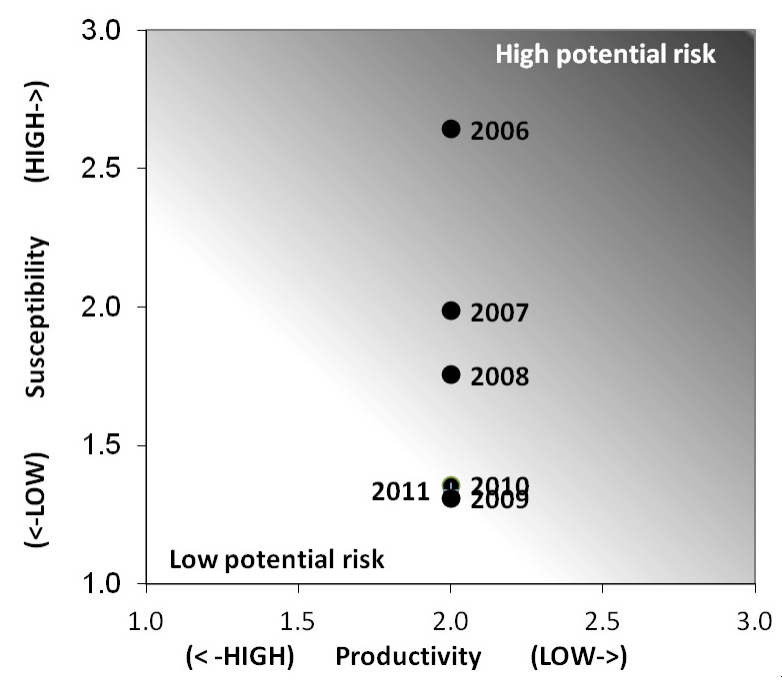

Fig. 7. Time-dependent PSA plot: the $x$-axis gives average scores of the attributes that dependent the productivity of orange roughy; the $y$-axis gives the scaled scores of attributes that influence the susceptibility of orange roughy to the impacts from deepwater fishing in the study area between 2006 and 2011. Productivity and susceptibility scores are used to calculated the euclidian distance and indicate the relative risk of the fishery to the species.

\subsection{Time dependant PSA analysis for orange roughy}

Availability scores were given according to the spatial overlap between the distribution of orange roughy and the distribution of deepwater fishing effort as monitored by VMS. In $2006,70 \%$ of the cells intersected, these figures decreased to $19 \%$ by 2009 and remained at $25 \%$ for the last year (Fig. 6). The main reduction in overlap over time could be observed on the western and south-western slopes of Porcupine Bank. The highest consistent overlap through time was evident on the northern slope of Porcupine Bank and the continental slope northwest of Ireland. The depth of fishing effort decreased over time, but the $25 \%$ and $75 \%$ quantiles of the orange roughy distribution remain within the $25 \%$ and $75 \%$ quantiles of deepwater effort throughout the time series (with the exception of 2010), this resulted in a high encounterability for all years. Direct target fisheries with vessels fishing on spawning aggregations of orange roughy over seamounts decreased from 2007 onwards. This resulted in a change of susceptibility scores for migration reducing the risk from high during the period of actively targeting spawning aggregations to low when only mixed fisheries on the continental slopes caught orange roughy. Aggregated PSA scores ranged between 2.4 and 3.3 and there was a reduction in risk scores over time (Table 3, Fig. 7). Scores fell within the medium risk category for 2006 and decreased into the low risk category from 2007 onwards.

\section{Discussion}

Originally, productivity susceptibility analyses (PSA) were performed to evaluate the relative risk of a fishery to different stocks or species, whereby populations were scored according to their intrinsic vulnerability and their exposure to the particular fishery in question (Hobday et al. 2007; Patrick et al. 2010; Hobday et al. 2011). This method has been successfully applied in situations where the majority of stocks are data deficient such as in fisheries certifications by the Marine Stewardship Council ${ }^{1}$, for fisheries management under the Magnuson Stevens Fishery Conservation and Management Act in the US (Cope et al. 2011; Ormseth and Spencer 2011) and for management of bycatch species in Australia (Zhou and Griffiths 2008; Zhou et al. 2009). Here, as a first step, a PSA on the deepwater fish community is presented to analyse the relative vulnerability of orange roughy in relation to other species of the mixed deepwater trawl fishery operated to the west of Ireland and Britain. In a further application, the PSA approach is used on a single species to evaluate whether and how the risk of recent deepwater fisheries has changed over time. This stems from the necessity to develop a form of risk assessment for a population that is considered depleted. The population is data deficient with regards to fisheries-dependent and independent data due to closed fisheries and a lack of scientific monitoring programmes. Using the PSA on one species means that the productivity attributes are fixed in time and the focus of the analysis is on the relative susceptibility of the species to fisheries and their changes over time. This is a new application of the PSA that we think could be used for a number of datapoor populations, such as those ray and shark species that are subject to 0 TAC in EU waters.

The PSA on deepwater species highlighted that there is variation of biological productivities in the fish community, ranging from relatively fast growing and productive species such as Lepidion eques, which has a relative vulnerability score of 1.3, to large-bodied and slow-growing shark species such as Centrophorus squamosus, which has a relative vulnerability score of 2.9. There are differences between taxonomic groups, with elasmobranchs being intrinsically more vulnerable to fishing than teleosts, and differences within taxonomic groups, resulting in the more vulnerable teleosts such as orange roughy and roundnose grenadier receiving similar scores to the more productive elasmobranch species Etmopterus spinax. Note that for black scabbardfish, the most conservative life history parameters were selected (Kelly et al. 1998) although all other studies suggest shorter longevity and faster growth (Morales-Nin et al. 2002; Pajuelo et al. 2008; Vieira et al. 2009; Delgado et al. 2013). As shown by a metaanalysis on the life history traits of deepwater species (Drazen and Haedrich 2012), the least productive species within each taxonomic group were the ones inhabiting the deeper depth zones.

In the original approach developed by Hobday et al. (2007), seven attributes were used to describe a stock's productivity. When the productivity of orange roughy in the Northeast Atlantic was scored accordingly, the species fell into the medium productivity category. Although orange roughy reaches a centenary life span (Andrews et al. 2009), its maximum size of less than $100 \mathrm{~cm}$ falls into the medium productivity and risk category together with roundnose grenadier and black scabbardfish. While the low productivity scores of roundnose grenadier and black scabbardfish were mainly due

\footnotetext{
${ }^{1}$ Marine-Stewardship-Council, 2012, MSC Certification Requirements. London, www.msc.org
} 
to their body length, for orange roughy they resulted from its longevity. In this deepwater species PSA, scoring categories have been adjusted to account for the overall longevity of the deepwater species and uses the maximum age of orange roughy as the extreme end of the scale. In terms of populations growth rate, orange roughy is one of the least productive deepwater species (Drazen and Haedrich 2012) with a high intrinsic vulnerability index (Norse et al. 2012). The fact that roundnose grenadier and black scabbardfish have similar productivity scores as orange roughy comes from the account of its relative moderate size and high fecundity. In contrast, the deepwater sharks, such as Centroscymnus coelolepis and Centrophorus squamosus, fell into the low productivity category. In addition to their large body sizes and high longevity, their low reproductive potential increases their vulnerability still further (Clarke et al. 2003), which was fully reflected in the multispecies PSA output.

The susceptibility of orange roughy to current and historical fisheries was evaluated by carrying out a high resolution analysis of the spatial overlap between the distribution of the stock and the spatial footprint of recent fisheries. For this purpose, every suitable data source for the biological distribution was aggregated over a time period of about 10 years, including data from fisheries-dependent and -independent monitoring programmes. This approach would not be suitable for a highly mobile or short-lived species, as it could not be ascertained whether the species distribution was stable over time. Orange roughy in the NEA, on the other hand, has several life history traits that allow the assumption that their spatial distribution has not significantly changed over the study period. Orange roughy can reach maximum ages of over 100 years (Thomsen 1998; Nolan 2004; Shephard and Rogan 2004; Andrews et al. 2009) and a decade represents less than $10 \%$ of its life expectancy. They form close habitat associations with bathymetric features such as seamounts and canyons, which are stable structures and allow the formation of smallscaled local populations (Carlsson et al. 2011), among which a certain degree of genetic connectivity allows for global panmixia (Varela et al. 2012). Empirical evidence such as biomass and catch rate reductions as well as distribution-contraction over time provide evidence for the susceptibility of orange roughy worldwide (Clark et al. 2000; Branch 2001; Francis and Clark 2005) as well as to the west of the British Isles (Lorance and Dupouy 2001).

The distribution of orange roughy in the study area should not be regarded as a definite distribution, as it was not based on a systematic spatial survey, but an amalgamation of different data sources. The aim of this study was to use the most extensive data available to establish where orange roughy occur, but not to draw conclusions on extent. In order to confirm the absence of orange roughy, sampling would need to be conducted with a more extensive and systematic spatial coverage.

The calculation of spatial overlap is highly dependent on the choice of grid size (Piet and Quirijns 2009; Lambert et al. 2012). Studies have shown that at grid cells of around $10 \mathrm{~km}$ and lower, there is a marked reduction in the error in calculated extent, suggesting that cells of that size are appropriate for describing the footprint of trawling (Mills et al. 2007) but increased resolution improves the accuracy of the footprint as this makes it more comparable with the actual widths of trawls (Piet and Hintzen 2012). In this study, a grid size of 1.8 min longitude by 1.2 min latitude was applied.

The results show that there was large spatial overlap at the beginning of the study when $71 \%$ of the biological distribution intersected with the extent of deepwater fisheries. At the onset of this study in 2006, the orange roughy TAC for VII was $1149 \mathrm{t}$ and landings were $488 \mathrm{t}$, which were primarily caught in a directed fishery (ICES 2011). TACs reduced to 0 within a timeframe of four years and landings decreased accordingly as deepwater fleets discontinued target fisheries for orange roughy. In addition, several spatial management measures were introduced, including, in 2007, orange roughy protection areas from which no orange roughy could be landed and offshore areas of special conservation for the protection of vulnerable marine ecosystems (VME), which banned fishing with bottom impacting gear from 2008 onwards (EC 2007). The discontinuation of a directed fishery through management is reflected in the change of fishing positions, which moved away from historic areas where directed fisheries were executed on bathymetric features such as mounds, ridges and canyons. This is particularly apparent on the western and south-western parts of Porcupine Bank with its high concentrations of canyons and mounds, which had been identified as areas of high orange roughy abundance (O'Donnell et al. 2007). The change in fishing pattern resulted in a decrease of PSA scores from a high risk category to a relatively low risk category. The fishery subsequently developed into a mixed fishery on flat fishing grounds targeting roundnose grenadier and black scabbardfish. The areas where these fisheries are still in operation are the "flats" fishing grounds on the continental slope to the northwest of Ireland, extending to the west of Scotland. Distribution maps of orange roughy and the deepwater fishing effort indicate that there is still some spatial overlap in this area. One geographical region worth highlighting is the northern slope of the Porcupine Bank. Fishing effort had ceased in this location in 2009 but returned in 2010 and 2011. In the same area, positive catch rates from the Irish deepwater trawl survey in 2007-2009 confirmed the presence of orange roughy. These areas are flat fishing grounds and with both juveniles and adults (O'Donnell et al. 2007; ICES 2011), which are believed to migrate to bathymetric features to spawn (Shephard et al. 2007). Thus, although the risk has decreased over the study period, as indicated by the PSA, some risk stills remains in certain locations. In order to evaluate whether certain life stages are more at risk than others, the PSA could be increased in complexity by splitting the susceptibility attributes into different life stage categories, i.e., juveniles and spawners, and assessing their vulnerability separately. By increasing the complexity of the model, it could account for the depth distribution of immature orange roughy that were observed to be distributed deeper than mature fish in Irish surveys, a factor that might decrease the overall species susceptibility. However, a more complex model would also be more data-demanding for all species.

Acknowledgements. We would like to thank all scientists and skippers for their cooperation in the provision of survey and observer data. Francis Neat from Marine Scotland Science is thanked in particular 
Brendan O'Hea and Graham Johnston from the Marine Institute deepwater survey programme. We also thank the two anonymous reviewers whose comments greatly improved the quality of the manuscript. This study was funded under the DEEPFISHMAN project, Management and monitoring of deep-sea fisheries and stocks, Grant agreement No. 227390.

\section{References}

Allain V., 2001, Reproductive strategies of three deep-water benthopelagic fishes from the northeast Atlantic Ocean. Fish. Res. 51, 165-176.

Andrews A.H., Tracey D.M., Dunn M.R., 2009, Lead-radium dating of orange roughy (Hoplostethus atlanticus): validation of a centenarian life span. Can. J. Fish. Aquat. Sci. 66, 1130-1140.

Branch T.A., 2001, A review of orange roughy Hoplostethus atlanticus fisheries, estimation methods, biology and stock structure. South. Afr. J. Aquat. Sci. 23, 181-203.

Bridger J.P., 1978, New deep-water trawling grounds to the West of Britain. Ministry of Agriculture Fisheries and Food (MAFF), Lowestoft.

Carlsson J., Shephard S., Coughlan J., Trueman C.N., Rogan E., Cross T.F., 2011, Fine-scale population structure in a deep-sea teleost (orange roughy, Hoplostethus atlanticus). Deep Sea Res. Part I, 58, 627-636.

Casas J.M., Pineiro C., 2000, Growth and age estimation of greater fork-beard (Phycis blennoides Bruennich, 1768) in the north and northwest of the Iberian Peninsula (ICES Division VIIIc and Ixa). Fish. Res. 47, 19-25.

Clark M., 2001, Are deepwater fisheries sustainable? The example of orange roughy (Hoplostethus atlanticus) in New Zealand. Fish. Res. 51, 123-135.

Clark M.R., Anderson O.F., Francis R.I.C.C., Tracey D.M., 2000, The effects of commercial exploitation on orange roughy (Hoplosthetus atlanticus) from the continental slope of the Chatham Rise, New Zealand, from 1979 to 1997. Fish. Res. 45, 217-238.

Clarke M.W., Connolly P.L., Bracken J.J., 2001, Aspects of reproduction of the deep water sharks Centroscymnus coelolepis and Centrophorus squamosus from west of Ireland and Scotland. J. Mar. Biol. Assoc. UK 81, 1019-1029.

Clarke M.W., Connolly P.L., Bracken J.J., 2001, Biology of exploited deep-water sharks west of Ireland and Scotland Scientific Council Meeting: Deep-sea Fisheries Symp. Northwest Atlantic Fisheries Organization.

Clarke M.W., Connolly P.L., Bracken J.J., 2002, Age estimation of the exploited deepwater shark Centrophorus squamosus from the continental slopes of the Rockall Trough and Porcupine Bank. J. Fish Biol. 60, 501-514.

Clarke M.W., Kelly C.J., Connolly P.L., Molloy J.P., 2003, A life history approach to the assessment and management of deepwater fisheries in the Northeast Atlantic. J. NorthwestAtl. Fish. Sci. 31, 401-411.

Coelho R., Erzini K., 2005, Lenth at first maturity of two species of lantern sharks (Etmopterus spinax and Etmopterus pusillus) off southern Portugal. J. Mar. Biol. Assoc. UK 85, 1163-1165.

Coelho R., Erzini K., 2008, Life history of a wide-ranging deepwater lantern shark in the north-east Atlantic, Etmopterus spinax
(Chondrichthyes: Etmopteridae), with implications for conservation. J. Fish. Biol. 73, 1419-1443.

Cohen D.M., Inada T., Iwamoto T., Scialabba N., 1990, FAO species catalogue. Vol. 10. Gadiforme fishes of the world (Order Gadiformes). An annotated and illustrated catalogue of cods, hakes, grenadiers and other gadiforme fishes known to date. FAO fisheries synopsis.

Cope J.M., DeVore J., Dick E.J., Ames K., Budrick J., Erickson D.L., Grebel J., Hanshew G., Jones R., Mattes L., Niles C., Williams S., 2011, An approach to defining stock complexes for US West coast groundfishes using vulnerabilities and ecological distributions. N Am. J. Fish. Manage. 31, 589-604.

Delgado J., Reis S., González J.A., Isidro E., Biscoito M., Freitas M., Tuset V.M., 2013, Reproduction and growth of Aphanopus carbo and A. intermedius (Teleostei: Trichiuridae) in the northeastern Atlantic. J. Appl. Ichthyol. 1-7.

Drazen J.C., Haedrich R.L., 2012, A continuum of life histories in deep-sea demersal fishes. Deep Sea Res. Part I, 61, 34-42.

EC, 2002, Council Regulation (EC) No 2347/2002 of 16 December 2002 establishing specific access requirements and associated conditions applicable to fishing for deep-sea stocks, Official Journal of the European Union.

EC, 2003, Commission Regulation (EC) No.2244/2003 of 18 December 2003 laying down detailed provisions regarding satellite-based vessel monitoring systems, Official Journal of the European Union, pp. 17-27.

EC, 2007, Council Regulation (EC) No 1533/2007 of 17 December 2007 amending regulations (EC) No 2015/2006 and (EC) No $41 / 2007$, as regards to fishing opportunities and associated conditions for certain fish stocks, Official Journal of the European Union, pp. 21-32.

Ehrich S., 1983, On the occurrence of some fish species at the slopes of the Rockall Trough. Arch. Fisch. 33, 105-150.

Figueiredo I., Bordalo-Machado P., Reis S., Sena-Carvalho D., Blasdale T., Newton A., Gordo L.S., 2003, Observations on the reproductive cycle of the black scabbardfish (Aphanopus carbo Lowe, 1839) in the NE Atlantic. ICES J. Mar. Sci. 60, 774-779.

Francis C.R.I.C., Clark M.R., 2005, Sustainability issues for orange roughy Fisheries. Bull. Mar. Sci. 76, 337-352.

Gerritsen H., Lordan C., 2011, Integrating vessel monitoring systems (VMS) data with daily catch data from logbooks to explore the spatial distribution of catch and effort at high resolution. ICES J. Mar. Sci. 68, 245-252.

Gerritsen H.D., Minto C., Lordan C., 2013, How much of the seabed is impacted by mobile fishing gear? Absolute estimates from Vessel Monitoring System (VMS) point data. ICES J. Mar. Sci. 70, 523-531.

Girard M., Du Buit M.H., 1999, Reproductive biology of two deepwater sharks from the British Isles, Centroscymnus coelolepis and Centrophorus squamosus. J. Mar. Biol. Assoc. UK 79, 923-931.

Gordon J.D.M., Bergstad O.A., 1992, Species composition of demersal fish in the Rockall Trough, northeastern Atlantic, as determined by different trawls. J. Mar. Biol. Assoc. UK 72, 213-230.

Gordon J.D.M., Duncan J.A.R., 1985, The biology of fish of the family Moridae in the deep-water of the Rockall Trough. J. Mar. Biol. Assoc. UK 65, 475-485.

Hobday A.J., Smith A., Webb H., Daley R., Wayte S., Bulman C., Dowdney J., Williams A., Sporcic M., Dambacher J., Fuller M., Walker T., 2007, Ecological risk assessment for the effects of fishing: methodology report for the Australian Fisheries Management Authority, Canberra. 
Hobday A.J., Smith A.D.M., Stobutzki I.C., Bulman C., Daley R., Dambacher J.M., Deng R.A., Dowdney J., Fuller M., Furlani D., Griffiths S.P., Johnson D., Kenyon R., Knuckey I.A., Ling S.D., Pitcher R., Sainsbury K.J., Sporcic M., Smith T., Turnbull C., Walker T.I., Wayte S.E., Webb H., Williams A., Wise B.S., Zhou S., 2011, Ecological risk assessment for the effects of fishing. Fish. Res. 108, 372-384.

ICES, 2011, Report of the Working Group on the Biology and Assessment of Deep-sea Fisheries Resources (WGDEEP). Copenhagen.

ICES, 2012, Report of the Working Group on the Biology and Assessment of Deep-sea Fisheries Resources (WGDEEP). Copenhagen.

ICES, 2011, Report of the Working Group on the Biology and Assessment of Deep-sea Fisheries Resources (WGDEEP). Copenhagen, 2-8 March.

Johnston G., O'Hea B., Dransfeld L., 2010, Fish species recorded during deepwater trawl surveys on the continental shelf and the Porcupine Bank, 2006-2008. Ir. Nat. J. 31, 130-133.

Kelly C.J., Connolly P.L., Bracken J.J., 1997, Age estimation, growth, maturity and distribution of the roundnose grenadier from the Rockall trough. J. Fish. Biol. 50, 1-17.

Kelly C.J., Connolly P.L., Clarke M.W., 1998, The deep water fisheries of the Rockall Trough; some insights gleaned from Irish survey data. ICES, Copenhagen.

Kulka D.W., Themelis D.E., Halliday R.G., 2003, Orange roughy (Hoplostethus atlanticus Collett 1889) in the Northwest Atlantic. J. NW Atl. Fish. Sci. 31, 10-56.

Lambert G.I., Jennings S., Hiddink J.G., Hintzen N.T., Hinz H., Kaiser M.J., Murray L.G., 2012, Implications of using alternative methods of vessel monitoring system (VMS) data analysis to describe fishing activities and impacts. ICES J. Mar. Sci. 69, 682-693.

Lorance P., Dupouy H., 2001, CPUE abundance indices of the main target species of the French deep-water fishery in ICES Sub-areas V-VII. Fish. Res. 51, 137-149.

Lorance P., Dupouy H., Allain V., 2001, Assessment of the roundnose grenadier (Coryphaenoides rupestris) stock in the Rockall Trough and neighbouring areas (ICES Sub-areas V-VII). Fish. Res. 51, 151-163.

Lorance P., Trenkel V.M., 2006, Variability in natural behaviour, and observed reactions to an ROV, by mid- slope fish species. J. Exp. Mar. Biol. Ecol. 332, 106-119.

Marine-Institute, 2012, Atlas of Irish Groundfish Trawl Surveys. Supporting fish stock assessment and new ecosystem advice.

Magnusson J.V., 2001, Distribution and some other biological parameters of two morid species Lepidion eques (Guenther, 1887) and Antimora rostrata (Guenther, 1878) in Icelandic waters. Fish. Res. 51, 267-281.

Merrett N.R., Haedrich R.L., Gordon J.D.M., Stehmann M., 1991, Deep demersal fish assemblage structure in the Porcupine Seabight (eastern north Atlantic) slope: results of single warp trawling at lower slope to abyssal soundings. J. Mar. Biol. Assoc. UK 71, 359-373.

Mills C.M., Townsend S.E., Jennings S., Eastwood P.D., Houghton C.A., 2007, Estimating high resolution trawl fishing effort from satellite-based vessel monitoring system data. ICES J. Mar. Sci. 64, 248-255.

Minto C., Nolan C.P., 2006, Fecundity and maturity of orange roughy (Hoplostethus atlanticus Collett 1889) on the Porcupine Bank, Northeast Atlantic. Environ. Biol. Fishes 77, 39-50.
Morales-Nin B., Canha A., Casas M., Figuereido I., Gordo L.S., Gordon J.D., Gouveia E., Pineiro C.G., Reis S., Reis A., Swan S.C., 2002, Intercalibration of age readings of deepwater black scabbardfish, Aphanopus carbo (Lowe, 1839). ICES J. Mar. Sci. $59,352-364$.

Moura T., Figueiredo I., 2013, Reproductive strategy and population structure of Centroscymnus coelolepis. In: WGEF W.D.t.I. (Ed.).

Muus B.J., Nielsen J.G., 1999, Sea fish Scandinavian Fishing Year Book. Hedehusene, Denmark.

Neat F., Burns F., 2010, Stable abundance, but changing size structure in grenadier fishes (Macrouridae) over a decade (1998-2008) in which deepwater fisheries became regulated. Deep Sea Res. Part I 57, 434-440.

Neves A., Vieira A.R., Farias I., Figueiredo I., Sequeira V., Gordo L.S., 2009, Reproductive strategies in black scabbardfish (Aphanopus carbo Lowe, 1839) from the NE Atlantic. Scient. Mar. 73, 19-31.

Nolan C.P.E., 2004, A technical and scientific record of experimental fishing for deepwater species in the Northeast Atlantic, by Irish fishing vessels, in 2001 BIM Fisheries Resource Series.

Norse E.A., Brooke S., Cheung W.W.L., Clark M.R., Ekeland I., Froese R., Gjerde K.M., Haedrich R.L., Heppell S.S., Morato T., Morgan L.E., Pauly D., Sumaila R., Watson R., 2012, Sustainability of deep-sea fisheries. Mar. Policy 36, 307-320.

O'Donnell C., Macaulay G., Doonan I., Grehan A., Roar-Hareide N., Ullgren J., Mackey M., Sachetti F., Sheppard S., 2007, An acoustic survey of orange roughy aggregations to the west and north of the Porcupine Bank. Marine Institute, Galway. Irish Fisheries Investigations.

Ormseth O.A., Spencer P.D., 2011, An assessment of vulnerability in Alaska groundfish. Fish. Res. 112, 127-133.

Pajuelo J.G., Gonzalez J.A., Santana J.I., Lorenzo J.M., GarciaMederos A., Tuset V., 2008, Biological parameters of the bathyal fish black scabbardfish (Aphanopus carbo Lowe, 1839) off the Canary Islands, Central-east Atlantic. Fish. Res. 92, 140-147.

Pankhurst N.W., McMillan P.J., Tracey D.M., 1987, Seasonal reproductive cycles in three commercially exploited fishes from the slope waters off New Zealand. J. Fish Biol. 30, 193-211.

Patrick W.S., Spencer P., Link J., Cope J., Field J., Kobayashi D., Lawson P., Gedamke T., Cortes E., Ormseth O., Bigelow K., Overholtz W., 2010, Using productivity and susceptibility indices to assess the vulnerability of United States fish stocks to overfishing. Fish. Bull. 108, 305-322.

Piet G.J., Hintzen N.T., 2012, Indicators of fishing pressure and seafloor integrity. ICES J. Mar. Sci. 69, 1850-1858.

Piet G.J., Quirijns F.J., 2009, The importance of scale for fishing impact estimations. Can. J. Fish. Aquat. Sci. 66, 829-835.

Priede I.G., Godbold J.A., Niedzielski T., Collins M.A., Bailey D.M., Gordon J.D.M., Zuur A.F., 2011, A review of the spatial extent of fishery effects and species vulnerability of the deep-sea demersal fish assemblage of the Porcupine Seabight, Northeast Atlantic Ocean (ICES Subarea VII). ICES J. Mar. Sci. 68, 281-289.

Rotllant G., Moranta J., Massutí E., Sardá F., Morales-Nin B.R., 2002, Reproductive biology of three gadiforme fish species through the Mediterranean deep-sea range (147-1850 m) Scient. Mar. 66, 157-166.

Shephard S., Rogan E., 2004, The assessment of orange roughy (Hoplostethus atlanticus) stocks in the deep waters off the west coast of Ireland using acoustic survey techniques. Final Report for the Strategic Marine RTDI Programme, Marine Institute. 
Shephard S., Rogan E., 2006, Seasonal distribution of orange roughy (Hoplostethus atlanticus) on the Porcupine Bank west of Ireland. Fish. Res. 77, 17-23.

Shephard S., Trueman C., Rickaby R., Rogan E., 2007, Juvenile life history of NE Atlantic orange roughy from otolith stable isotopes. Deep Sea Res. Part I, 54, 1221-1230.

Thomsen B., 1998, Faroese quest of orange roughy in the north Atlantic. ICES Doc. CM O:3

Varela A., Ritchie P., Smith P., 2012, Low levels of global genetic differentiation and population expansion in the deep-sea teleost Hoplostethus atlanticus revealed by mitochondrial DNA sequences. Mar. Biol. 159, 1049-1060.
Vieira A.R., Farias I., Figueiredo I., Neves A., Morales-Nin B., Sequeira V., Martins M.R., Gordo L.S., 2009, Age and growth of black scabbardfish (Aphanopus carbo Lowe, 1839) in the southern NE Atlantic. Scient. Mar. 73, 33-46.

Zhou S., Griffiths S.P., 2008, Sustainability assessment for fishing effects (SAFE): a new quantitative ecological risk assessment method and its application to elasmobranch bycatch in an Australian trawl fishery. Fish. Res. 91, 56-68.

Zhou S., Griffiths S.P., Miller M., 2009, Sustainability assessment for fishing effects (SAFE) on highly diverse and data-limited fish bycatch in a tropical prawn trawl fishery. Mar. Freshw. Res. 60, 563 570. 